Original article

\title{
PUBLIC MANAGEMENT REFORMS IN TURKEY
}

\section{Fatih Demir}

Manisa Celal Bayar University, Department of Public Administration.

Address: IIBF Şehit Prof. Dr. İlhan Varank Kampüsü 45140 - Yunusemre - MANİSA.

E-mail: fatihdemir.dr@gmail.com

\begin{abstract}
This article focuses on public management reforms in Turkey and how the reform trajectory has changed over the past two decades. Reforms in Turkey represent a mixture of ideas and reform elements that are constantly evolving under the influence of foreign actors, especially the European Union, efforts to respond to global reform trends, and domestic political developments. The article is divided into three parts. The first part gives a brief picture of the political-administrative structure of the country. The second part provides a landscape of the reform initiatives in the last two decades. The third part examines the main challenges Turkey might face in the coming years in terms of implementing reforms and provides a discussion on how they can be addressed.
\end{abstract}

Keywords: public management, reforms, Turkey, bureaucracy.

For citation: Demir, F. (2021) 'Public management reforms in Turkey', Public Administration Issues, 6 (Special Issue II, electronic edition), pp. 63-83 (in English). DOI: 10.17323/1999-5431-2021-0-6-63-83.

\section{Introduction}

In the aftermath of the 1980s, a significant paradigm shift was observed in the area of government in line with efforts to reduce the size of the state while increasing its efficiency and effectiveness. Within the scope of reforms carried out in public management, concepts such as total quality, governance, participation, transparency, strategic planning, and performance occupy a special place ${ }^{1}$.

\footnotetext{
1 For detailed discussion of the content of public management reforms in the 1980s, see Radaelli and Meuwese (2009), Schick (1996), Piotrowski (2008), Ongaro (2009) and Rouban (1999).
} 
In the following sections, the public management reforms in the post-2000 period will be evaluated in the context of both national and international actors and major legal regulations. The aim here is to present recent dramatic reform initiatives without overlooking the impact of the European Union accession process and to evaluate the main challenges Turkey might face in the coming years in terms of implementing reform and discuss how they can be addressed.

\section{The political-administrative context}

Restructuring efforts in Turkish public administration date back to the $19^{\text {th }}$ century. In the beginning of the modernization process, the Turkish public administration system was inspired by the French system as a result of Westernization efforts. Its change over time was again largely parallel to the developments in Europe. Thus, it can be claimed that reform efforts in Turkey have been an important issue since the Tanzimat era (1839-76). Especially during the Tanzimat, First Constitutional (1876-78) and Second Constitutional Eras (1908-1918), reforms and reform efforts gained momentum, which continued in a similar pattern in the Republican period.

Early reform work in the Republican period consists of reports and projects. The most distinctive feature of the administrative reform efforts of this period is that these reforms were prepared by foreign experts and were carried out especially after the 1930s. The reforms were named after the foreign expert who prepared the reports. The Dorr Report, Neumark Report, Barker Report and MartinCush Report are the main examples of these reform efforts.

The first most comprehensive and detailed reform study of the Republican period was the "Dorr Report" prepared by Goldthwaite H. Dorr in 1933. In this document, it was mentioned that development could be achieved by focusing on private enterprises. In addition, it was stated that red tape, which was one of the biggest obstacles to development, should be eliminated and public administrators should devote more time to important issues by transferring their powers arising from centralization. The report was not limited to these problems and suggestions, and tried to cover a wide range of issues by addressing almost all of the national issues of the period, which made implementation of the recommendations in the report difficult (Daniel, 1967).

The "Report on Rational Working Principles in State Departments and Institutions" prepared by Prof. Dr. Fritz Neumark, a faculty member of Istanbul University, is the result of another reform work in Turkey. In this report, by researching the Turkish personnel system, Neumark suggested strengthening the deficiencies of the personnel system, to ensure a balanced distribution of public personnel, to improve the salary system, and to reduce unnecessary personnel costs. In addition to the problems related to personnel, the Neumark Report also examined the deficiencies related to the organization, the inadequacies of the laws, the problems caused by the paperwork and formalities, and the problems caused by the inspection and control system were also evaluated (Ege and Hagemann, 2012, pp. 955-961). These are important problem areas that still exist today. The report approached the problems in Turkey in a sincere and realistic way. 
Another important reform effort carried out in this period was the study prepared in 1951 which is known as the Barker Report. The recommendations of James M. Barker can be categorized into two main groups: (i) coordination of economic problems, establishment of a better management mechanism, strengthening private enterprise, ensuring financial stability, regulating education and health problems, and (ii) handling agricultural problems and training technical and administrative staff (Zanotti, 2016). In the report, besides the inadequacies of civil servants and organizational deficiencies, the inconvenience of the laws, excessive paperwork and the problems in the inspection-control system were also listed (Yayman, 2008, p. 131).

The Martin-Cush Report, which foresaw the restructuring of the Ministry of Finance and was published at the same time as the Barker Report, was a reform project focused on the administrative, economic and social problems of the period (Altan, 2016).

The reform studies in the period of 1960 and 1980 were not comprehensive. The most important reform of the period is the Central Government Organization Research Project, and it is the first comprehensive study on Turkish public administration to consider the organization and its functioning as a whole (Sezen, 2011, pp. 333-337; Kapucu and Palabıyık, 2008).

The period of 1980 and 1990 was a time when reform efforts were in line with development plans and were influenced by international trends, especially the new public management (NPM). During this period, the Public Administration Research Project, the January 24 Decisions and the change in the economy (transition from the import substitution model to the export-based economy) made public administration reform obligatory. Between 1990 and 2000, steps that could be considered as part of public administration reform could not be taken. The main reasons being that there was an economic crisis in 1994 and a politically unstable landscape (Gül and Kiriş, 2015). Privatization and deregulation continued at full speed.

The reform efforts continued parallel to the NPM as well as the interaction with supranational organizations such as the European Union and the pressures of domestic political developments. The reconstruction efforts became more concrete in the last two decades when they finally reached a certain level within the framework of the reform packages predicting a holistic change in public administration in early 2000s. In this context, the traditional tendencies that dominated the central and local governments in the Turkish political system in terms of administrative, political and financial organization of the state apparatus, and relations between central authority and other actors in the society began to change (Sezen, 2011). This could well mark the beginning of a transition to a public administration approach that is in line with contemporary forms introduced by the new public management paradigm which, for example, argues that local governments should be strengthened in terms of duties, powers and resources, and governance should become more participatory and democratic in operation.

\section{New Public Management Reforms in the 2000s}

The 2000s have been the years when reforms were introduced and implemented in the Turkish public administration especially within the framework of NPM 
understanding. In this period, apart from the discourses and practices that include principles such as downsizing the state, reducing bureaucracy, increasing competition, focusing on private sector techniques, and increasing localization, which are major arguments of NPM, a special importance has been given to principles and values such as the right to information, openness, transparency and participation.

Considering the history of public administration reforms in Turkey in the early 2000s, it can be seen that issues are classified in terms of financial management, local governments, and oversight of the government (Gül and Kiriş, 2015; Kapucu and Palabiyık, 2008). In fact, 2003 can be considered a turning point as regards administrative and financial reforms of Turkish Public Administration. In terms of public finance, the General Accounting Law, which remained from the Ottoman period until that time, was in effect for many years until 2003 when the Public Financial Management and Control Law No. 5018 was enacted and a new management understanding and implementation was initiated. With this law, a management approach based on strategic management and performance was put into effect for the first time in public administration. In the first article of Law No. 5018, the purpose of the law is described as ensuring the provision of public resources effectively, economically and efficiently, as well as accountability and financial transparency. In the law, accountability is defined as the responsibility of those who are assigned and authorized to use resources for any misuse and illegal use of resources towards the competent authorities. Financial transparency (art.7) is defined as informing the public in order to ensure control of obtaining and using resources.

In 2003, under the leadership of the Prime Ministry, a report titled "Change in Management for the Management of Change" (Dinçer and Yılmaz, 2003), which had a content that was compatible with the principles of new public management, was published under the auspices of the prime ministry. Focusing on reform efforts in public administration, the purpose of the report was revealing the need for reform, which should be done within the framework of the NPM understanding and vision of the twenty-first century, with mentality, strategic design and organizational dimensions, where competition and the individual would be at the forefront in accordance with the concepts introduced by globalization and information society (Dinçer and Yllmaz, 2003, p. 11). In this way, it was emphasized in the report that the public administration should catch up with the global changes through reforms.

\subsection{Right to Information}

Law No. 4982 on Right to Information was enacted in 2003 in order to ensure openness and participation in public administration. The purpose of this law (Art.1) has been determined as regulating the right of individuals to obtain information in an equal, impartial and open understanding in ensuring a democratic and transparent administration. It is stated in Law No. 4982 that everyone has the right to obtain information (Art.4) and that the relevant institutions and organizations are liable for the use of this right (Art.5) with certain exceptions.

The Right to Information Act was intended to ensure openness in government (Özdemirci, 2008). With this right, citizens are given the opportunity to re- 
quest all kinds of data, information and documents from all public institutions. The Right to Information Act made access to information the rule and restriction the exception. All an individual has to do is apply to the information offices of the relevant institutions and to request the information they want in order to benefit from this right. Government agencies must answer these applications within 15 working days. The existence of the right to information, in a sense, gives every citizen the role of honorary inspector, and ensures that the bureaucracy is controlled by the public. Thus, such openness is expected to make decision-making procedures known and aims to prevent public employees from violating the rules. With this law, the increased visibility of public activities made it difficult to cover up mistakes and arbitrariness.

\subsection{E-government}

E-Government refers to the structures that ensure the delivery of public services to the citizens, institutions and organizations that will use this service through information technologies (Fang, 2002, p. 2). In this way, faster, cheaper, efficient and reliable public service provision is targeted. The main objectives of egovernment applications can be listed as follows:

- $\quad$ reducing red tape and time loss in institutions;

- decreasing service costs;

- $\quad$ increasing individual participation, which will contribute to the development of democratic culture;

- eliminating repetitions through intensive communication between institutions and preventing waste of resources ${ }^{2}$.

Electronic Signature Law No. 5070, which is an important step in the transition to e-government application, entered into force in 2004. With this law, the foundation of the infrastructure that will allow official correspondence to be made in an electronic environment was laid. Systems such as MERNIS (population services), SAY 2000i (Information Flow between Accountants of the Ministry of Finance), UYAP (National Judicial Network), POL-NET (Police Services) can be cited as examples of e-government applications in Turkey.

\subsection{Public Sector Ethics}

In 2004, the Law on the Establishment of the Public Servants Ethics Board was adopted, the principles of ethical behavior that public officials should comply with while performing their services were determined, and the Ethics Board for Public Servants was established accordingly. The purpose of the law (Art.1) is determining and observing the principles of ethical behavior such as transparency, impartiality, honesty, accountability and observance of the public interest that public officials must comply with. Indeed, ethical principles are important in terms of ensuring the trust of the people in the administration and improving the quality of public services (Le Grand, 2009; Kirkpatrick et al., 2005). In 2004, the text of the "Draft Law on the Basic Principles and Restructuring of Public

\footnotetext{
2 The list is essentially valid for developing countries. It is compiled from Alhomod et al. (2012), Basu (2004), and Chen et al. (2006).
} 
Administration" was prepared, which envisaged the re-sharing of duties, powers and responsibilities of the public administration within central government and between central and local governments. The text of the draft included programs on the downsizing of the state and reducing the bureaucracy, which is one of the basic principles of the NPM understanding. However, this draft law was canceled by the Constitutional Court of the time upon the application of the president. Nevertheless, the draft law inspired subsequent reform studies to a certain extent and influenced them in significant ways including public sector ethics (Ataay, 2008).

\subsection{Ombudsman}

Due to developments in the world and in Turkey, the "Ombudsman Office" was introduced as a constitutional institution by making amendments to the Constitution with a referendum in September 2010. The office was expected to examine or alleviate the complaints of the people about the administration. Two years later, the Law on the Establishment of Ombudsman Institution was enacted and the institution became functional in 2012. With this law, the Ombudsman Institution was established for the first time in Turkish history and it was charged with the duty of examining, investigating and making recommendations regarding the functioning of public services so that all kinds of acts, transactions and behaviors of the administration could be performed based on human rights, law and fairness (Law No. 6328, Art.1). In addition, with the relevant law, it was stipulated that no body or authority could give orders, instructions or express opinions to this public legal entity (Article 4) and ombudsmen (Article 12), thus ensuring the impartiality and autonomy of the institution.

\subsection{Local Governance}

With Law No. 5216, which was enacted in 2004 as the first of a series of local government laws, administrative tutelage over metropolitan municipalities was eased. In the previous law, some transactions of the metropolitan municipality, such as the budget, were enacted with the approval of the appointed governor. In the new law, the implementation of the approval of the metropolitan municipality's operations by the governor, including the budget, has been ended. In addition, with the new law, the governor's supervisory authority over the processes of the decision-making bodies of the metropolitan municipality was terminated by removing the authority of the governor to appeal against the decisions of the metropolitan municipal council and the district municipal councils (Torlak and Sezer, 2005, p. 103). As can be seen from all these regulations, the administrative tutelage and auditing authorities of the central government over local governments has been reduced, while internal auditing and external auditing by the Court of Accounts have been strengthened (Eryllmaz, 2008, p. 154). In addition, with the Metropolitan Municipality Law No. 5216, attempts were made to integrate actors such as non-governmental organizations and universities in the decisionmaking processes. This practice was expected to create a local government which gives priority to participation and increase efficiency and productivity in services.

Other comprehensive legal regulations regarding local governments are the Provincial Special Administration Law No. 5302 and the Municipality Law No. 5393, 
both issued in 2005. The handling and regulation systems of the laws are very similar. In both laws, it is seen that local councils came to the forefront, the tutelage powers of the central government and its provincial extensions were softened, local powers and duties were increased and their autonomy emphasized, flexible organization was adopted, and new methods and concepts such as norm staff and strategic management were emphasized. With these new regulations, local governments gained a more pro-active and participatory management approach than in the past.

\subsection{Influence of the European Union}

The EU integration process represents the most important project in the Turkish modernization history and modernization effort. This project, which started in the second half of the $20^{\text {th }}$ century, has reached the stage of negotiations with the EU (in 2005) on the way to full membership. As a requirement of the stage reached in this process, Turkey tries to realize the legal and institutional transformations proposed by the Union and modernization trends in its countries (Kukovič, Justinek, 2020). The EU considers it safer to negotiate full membership with a candidate country that has adopted its standards in all areas, and also as a prerequisite for the Union to accept the candidate country as a member state.

The reason behind the European Union's orientation towards an effective, quality and efficient public administration is to arbitrate and build a managerial adaptation capacity that will enable candidate countries to implement social, economic and technological reforms. For this reason, the EU closely monitors the Turkish public administration's alignment with the European acquis and makes a due diligence, which includes recommendations and reports, prepared regularly every year. Through the reports, capacity competence is determined for the ability of "effective monitoring, supervision, surveillance and reporting" in terms of sectoral units of the public administration field. Turkish public administration is also expected to reorganize on the basis of the expectations, suggestions and evaluations expressed in the progress reports and to realize transformative-regulatory reforms that strengthen adaptation with the EU administrative space ${ }^{3}$.

It should be noted that the reform proposals directed to the candidate countries in the progress reports are based on a specific system and do not lack an intellectual background. Providing examples of structuring such as subsidiarity, effective-regulatory state, downsizing of the public sector, political-administrativelegal accountability, simplification of administrative procedures, making ethical principles effective in public administration, and expanding the governance and performance system, the new public management / entrepreneurial governance approach forms the main motivation and driving force of Turkish public administration reforms through the determinations and recommendations reflected in progress reports, and mediates the integration of global management values with the Turkish bureaucratic structure.

\footnotetext{
3 For analysis of Turkish public administration reforms and EU administrative space, see Soós (2016), Sungar (2005), Sözen and Shaw (2002), Koçak (2009).
} 


\section{Future Challenges of the Reforms in Turkey}

\subsection{Subsidiarity vs. Recentralization}

Subsidiarity is defined as the intervention of central public authority only when the local bodies cannot overcome the problems of the public (Van den Bergh, 1994; Follesdal, 1998). In this respect, in accordance with the subsidiarity principle, services should be provided by the administrative unit closest to the public (Mäeltsemees, 2013; Vischer, 2001). In this sense, it requires an organization from the bottom up, not from the top down. The relevant administrative unit should be determined depending on the scope, quality, efficiency and economy of the service ${ }^{4}$ Frieden (2004, p. 2265) states that the concept has an international dimension and that relations between international organizations and member states gain importance at this level. With these aspects, localization evokes a concept that has political, managerial and financial dimensions. In this context, it is argued that the process implies some dissolution of authority (Rhodes, 1996, p. 661).

On the other hand, transferring authority and duties to local organizations without improving the management capacity of local governments can make these organizations rather cumbersome and inoperable. While implementing the reform, the adequacy of local administrations in terms of personnel, technical and administrative capacity should also be evaluated vis-à-vis the scale of service delivery, public benefit, public service, impartiality, economy, accessibility of services, equality, and equity (Ayeni, 2002; Ohemeng and Owusu, 2014).

An evaluation of the local government reform in Turkey in terms of EU criteria shows that Turkey has complied with the European Charter of Local SelfGovernment and other relevant EU legislation to a certain extent. However, some problems can be pointed out in the establishment and implementation of the new governance understanding and culture envisaged by the reform (LoewendahlErtugal, 2005; Sözen, 2012). While the aims and steps towards decentralization were witnessed in public administration reforms between 2002 and 2011, practices towards centralization began to become more concrete in 2011. In this context, the authorities and tasks that were first delegated by the central government started to be taken back over time. To put it with more concrete examples, while the special provincial administrations were the most important administrative units of localization, they were later closed down with the Law No. 6360 which was enacted in $2012^{5}$. In addition, local governments over time lost some of their important powers to relevant ministries, especially the Ministry of Environment and Urbanization (MoEU). The Presidential Decree No. 1 which was put into force in 2018 required that local governments and relations between them would be regulated by the MoEU. According to this decree and following regulations, the powers and duties previously delegated to the local governments in early $2000 \mathrm{~s}$ were transferred back to the central government. For example, while the authori-

\footnotetext{
${ }^{4}$ Cass (1992) provides a comprehensive discussion on the legal and efficiency-related aspects of the principle of subsidiarity.

${ }^{5}$ Law No. 6360, Article 1(5) required that provincial special administrations in 30 of the 81 provinces would be abolished as of 2014 .
} 
ties and duties regarding urban transformation were given to the local government units in the previous regulations, they were transferred to the Housing Development Administration of Turkey (TOKI), which is affiliated to the MoEU, with the decrees issued in 2018 and 2019. Zoning, environmental and planning authorities were also in the local government units before they were transferred to the Ministry of Environment and Urbanization with the Presidential Decree No. 1 in $2018{ }^{6}$

Another example that can be given regarding the steps taken towards re-centralization is the Law No. 6360 enacted in 2012. As can be seen in the objectives of the law, such as making use of economies of scale sufficiently, ensuring more efficient use of resources, preventing waste of resources, and creating strong local government structures, economic reasons in particular were brought to the fore. However, it is clear that in this regulation, economic reasons were followed by political reasons and the boundaries of metropolitan municipalities were expanded to the provincial administrative boundaries, subjecting locally centralized bodies to the authority of a single elected metropolitan mayor. Law No. 6360 also poses an important problem in representation. In an environment where thousands of local government units have been abolished, the metropolitan municipality structure is given under the authority of a single elected mayor who is equipped with many duties and powers, in terms of both service provision and coordination (Savaş-Yavuzçehre, 2016).

The last step to be considered in the direction of re-centralization is the regulation that caused the supreme boards to be under the control of the ministries in 2011. Supreme boards, also known as independent administrative authorities, were established in the fields of banking, energy, competition and finance, known as the "sensitive sectors" in the 1990s. The main reason for these organizations to come to life is to provide an understanding of management that is far from the damaging interventions of politics for the sake of daily interests. It was claimed that over time, these organizations have almost declared their independence and that politics is the only structure that is accountable to the voters due to the economic problems experienced. ${ }^{7}$ These allegations were voiced strongly by many politicians over time, and the process resulted in the ministerial control of the supreme boards in 2011. New legislation stated that the ministers would supervise all kinds of activities and transactions of the relevant higher organizations, and thus a significant centralization was achieved on the supreme boards.

\subsection{Information technologies and transparency}

As regards e-government applications, it should be stated that the desired success has not been achieved due to reasons such as insufficient awareness of citizens on this issue, the fact that internet use is not widespread in all segments of society, lack of legal infrastructure, and insufficient investment in the sector due to limited financial opportunities. Turkey appears to rank last among Euro-

\footnotetext{
6 Detailed discussions of the issue can be seen in Angın and Övgün (2020), Bahçeci (2017) and Akbay (2020).

7 For comparative perspectives and case studies on the matter, see Grant and Keohane (2005) on USA, Follesdal and Hix (2006) and Olsen (2017) on the EU, Cox and McCubbins (1997) on Latin America, and McNamara (2002) and Goodhart and Lastra (2018) on central banks.
} 
pean countries in information technologies (Özcan, 2018). This means that even if the state is fully transferred to the electronic environment, a significant portion of the citizens will not have access to these services. It would thus be too optimistic to increase efficiency in public administration by purchasing computers for public institutions and preparing web pages. In other words, e-government studies are not only activities with technical dimensions, it will be beneficial to consider the issue with a more holistic perspective. For example, priorities such as continuous training of personnel working in public organizations, informing citizens as much as possible at different levels, and expecting that newly employed personnel are knowledgeable on information-communication technologies should be emphasized. In that way, information technologies, which are an important catalyst in the change process in public administration, can be used to the maximum extent.

One of the areas where the right to information is used most widely in Turkey is employees reviewing their performance evaluation results (Aydin, 2019, p. 135). Although it is a useful practice for the evaluated public official to see his / her own performance, it is a regulation that should be applied carefully in terms of the potential for conflict in superior-subordinate relations. Especially in a bureaucratic structure in which the merit system cannot be fully implemented in all aspects, this tension is likely to increase and in some cases serious conflicts may be the result between the evaluated personnel and the evaluating supervisor, which reduces the institutional efficiency.

Examination on the websites of provincial municipalities within the framework of the provisions of the Regulation on Principles and Procedures Regarding the Implementation of the Law on the Right to Information revealed that all provincial municipalities have deficiencies in the context of the right to information at varying degrees (Özdemirci, 2008, p. 308). Most of the information or documents required to be shared with the public within the scope of the right to information are not published by the municipalities (Sözen, 2012). More recent studies on the subject matter provide evidence that problems continue to plague transparency and accountability of government in Turkey. For example, most metropolitan municipalities do not publish the information and documents required to be published on the website in accordance with the provisions of the Regulation on Principles and Procedures Regarding the Implementation of the Law on the Right to Information. Most of the information and documents that the same regulation requires to be published in order to reduce the workload arising from applications for obtaining information are also not available on the internet pages (Emini and Ayaz, 2018). ${ }^{8}$ Another aspect of the right to informa-

\footnotetext{
8 Authors examined the web pages of 30 metropolitan municipalities and determined that there were no municipalities that included all of the mandatory elements specified in the regulation. İzmir Metropoli$\tan$ Municipality is the only municipality that included 8 of the 9 mandatory elements subject to examination, and all information and documents are available on the website, except for the audit report. However, there was no link or form on the website of 6 metropolitan municipalities (Gaziantep, Kayseri, Malatya, Mardin, Şanlıurfa and Van) regarding the application for information. On the website of Gaziantep Metropolitan Municipality, it was stated that the form in the contact section must be filled in for information access applications, but there is no option to obtain information in this form. Adana and Tekirdağ Metropolitan Municipalities redirect the applicants to the Presidential Communication Center (CIMER) page for information requests.
} 
tion is related to the low awareness level of the public as regards their rights to obtain and the duties of the government to provide information. Several studies indicate that since the effective date of the Law on the Right to Information, there are still serious deficiencies in knowledge about its content and using it for its purpose. İbiş and Akdağ (2015) found that in the case of Erciyes University the frequency of benefiting from the Right to Information Law was low and that the majority of the applications made to the unit consist of applications that did not comply with the content of the law.

Further problems are being experienced with the right to information and accountability of government in the case of applications filed to the Ombudsman. The Ombudsman Institution, which was introduced in Turkey in 2012 with the Ombudsman Law No. 6328, was established as a channel where the citizens can convey their complaints and requests in their relations with the administration (Demir, 2020, p. 99). Applications to the Ombudsman can be made to the governorship and district governorship in places where the institution does not have a communication office. Although applications to the institution can be made via e-mail, some documents still have to be delivered to the institution. Therefore, a completely paperless process has not been established. Kağıtçığlu (2018) provides evidence from field studies showing that in order for the Ombudsman's Office to include a national human rights institution in accordance with the Paris Principles, in addition to its current duties, it should be emphasized that it could conduct research in the field of human rights, engage in awareness and education activities, and improve human rights. In addition, it is essential that issues related to anti-discrimination and equality be included in the duties of the institution. According to the author, the duty field of the institution should not be limited to the operations and actions of the administration. In addition, the fact that the Ombudsman Institution does not have the authority to act ex officio constitutes a violation of the Paris Principles 9 (Güneş, 2018).

The current situation defined above, which is incompatible with the transparent and accountable government principles as well as the legislation, reveals that the accountability responsibility is not completely fulfilled. Although required by legislation, municipalities avoid sharing their basic decisions, tender processes, projects, annual reports and audit reports with the public. This situation is incompatible with the principle of openness, which is listed among the purposes of the Law on the Right to Information, and reveals that many critical processes are carried out in secrecy despite the legal regulations. In the current situation where the accountability of the management is not fulfilled and despite the legal regulations, the administrative processes are practically confidential, it becomes unreasonable to talk about the full use of the right to information. Restricting or even blocking access to information is also a serious obstacle to participation in governance.

\footnotetext{
9 The Paris Principles are a set of international principles, adopted by the United Nations General Assembly in 1991, which frame and guide the work of national human rights institutions (NHRIs). These principles require that these bodies be independent and have a broad human rights mandate, be adequately funded, and be appointed on the basis of an inclusive and transparent selection and appointment process. These principles set a standard for assessing the legitimacy and credibility of NHRIs. For detailed information see Duyck et al. (2018).
} 


\subsection{Evidence-based policy-making}

In the new presidential model, ministers and the president determine the policy agenda (for example, which law proposal will be enacted first), but this power is limited by the framework drawn by political, economic and social dynamics. The legislative and judicial bodies, academia, non-governmental organizations, think tanks, interest groups, the media and public opinion affect politicians in the public policy process. In addition, occasional situations such as disasters, major crises, and international opportunities also play an essential role. In other words, the power of ministers and the president to set the agenda is limited by many actors and factors. In addition, because of the limited number of laws that can be enacted in a legislature, which Simon (1972) calls the sequential process, politicians have to prioritize among problems under time pressure. In this prioritization, the promises given to the voters, the political party program and the desire to be successful are effective.

The appointed and elected directors of an administration that can collect evidence from within their own organization and do not share it with other administrations gain power and reputation in the process of public policy due to the information asymmetry. On the other hand, sharing evidence enables other actors to criticize the government's public policy and to come up with new policy recommendations. This leads to the administration's reluctance to share evidence. In the literature, it was stated that "information hiding" is essential and a widespread practice among administrations in Turkey (Öktem and Çiftçi, 2016). The fact that administrations do not share data and evidence with other administrations and other actors causes a lack of coordination in the production and presentation of evidence. The administrations produce data independently of each other on issues where their areas of duty intersect, and from time to time, inconsistencies arise between these data (Aydınoğlu and Kara, 2019). On the other hand, the capacity of administrations to provide evidence is limited by the lack of qualified personnel and difficulties in procuring services. Particularly, the contribution of civil servants in producing evidence seems important. In addition, it has been noted in the literature that Turkish administration is generally not sufficient in classifying the data it obtains and reporting in a way to detect meaningful patterns ${ }^{10}$. Although there is an opportunity to cooperate with the academy in this field, this mechanism is not operated adequately. The desire of politicians to rapidly implement their own agendas requires administrations to rapidly prepare a law proposal in some public policy areas and may force them to work with existing evidence instead of producing new and more up-to-date evidence. Efforts to quantify social benefits and costs incurred such as utility cost analysis and economic modeling are carried out in a very limited manner within the administration. Most studies attempt to prove the economic impact of one policy or another based on empirical evidence. Examples include evaluating evidence in health economics (Karaca and At1lgan, 2020), developing symmetric and asymmetric conditionally variance

\footnotetext{
${ }^{10}$ For discussions related to specific areas in Turkey, see İçduygu and Toktaş (2002) on migration, Keers et al. (2013) on hospitals, Sözbilir and Kutu (2008) on education, Isik and Singh (2008) and Onat and Ersöz (2011) on resource management, and Öztürk (2015) on urbanization.
} 
models to detect exchange rate volatility (Güler, 2017), testing the effectiveness of export-based development policies (Kara, 2020), investigating the correlation between military spending and economic growth (Topal, 2018), and measuring the welfare and growth costs of population policies (Attar, 2020).

It is argued that administrations may hide some data when presenting evidence to ministers, but will not deliberately distort the evidence. However, politicians can distort the evidence while sharing it with the public. Sharman and Holmes (2010) provided some insight into this problem in the case of biofuels. Beswick and Elstub (2017) offered detailed accounts of selective and biased use of evidence by lawmakers. Mulgan (2007) showed that evidence could easily be politicized, if not distorted, when it comes to sensitive issues such as national security. The decision-makers, on the other hand, have to make a decision by taking some of the evidence into account, since they do not have the time to examine and duly evaluate all evidence.

One of the most important functions of evidence-based policy making in Turkey is to increase the transparency of the administration and to ensure participation in policy making and accountability after policy implementation. Evidence is not neutral facts about social problems that merely show cause and effect relationships. Conflicting evidence and interpretations can be found on the same topic. In other words, the capacity of the evidence to define the problem and predict the consequences of the implementation of public policy is limited.

\section{Conclusions}

In the 2000s, Turkey witnessed major and important reform moves in many areas, especially in the economy, politics and social life. One of the most important areas of these reform moves is undoubtedly public administration. Establishing a structure based on the new public administration approach by getting rid of the traditional understanding of public administration has been among the main objectives of these efforts, and it has been declared repeatedly that the public administration would free itself from the cumbersome and bureaucratic structure as a result of this process (Kettl, 2015; Rhodes, 2000; Box et al., 2001). Thus, the legitimacy of state administration, which allegedly had been damaged to a great extent, would be restored by public administration reform. Public administration reform, which is among the most important projects of the governments established in the 2000s, embraces most areas of government from central government to local governments and from public finance to transparency of government.

With the reforms implemented in the Turkish public sector in the last 20 years, it is seen that an important transformation has been experienced. The starting point of these regulations is the new public management approach. Time is needed to see the extent and results of the principles adopted to provide answers to the social, economic, political and historical problems Turkey has been experiencing. The restructuring efforts in public administration, which seem in harmony with the efforts to articulate the European Union institutions and culture, also reflect concrete indicators that the strategy to catch up with global standards is being implemented. However, while the aims and steps towards decen- 
tralization were observed in the public administration reforms between 2002 and 2011, practices towards centralization began to become more concrete in 2011 . In this context, the authorities and tasks that were first delegated started to be taken back over time. To put it into more concrete examples, while the special provincial administrations were elevated to the position of being the leading actors in terms of local development (Ak1llı and Akıllı, 2014, p. 683), later they were either abolished (in metropolitan areas) or lost their leading position to municipalities as the main competent bodies in the field of development. Within a few years, they lost some of their remaining important powers to the Ministry of Development (Çetin, 2015; Çiner, 2014).

The results of public administration reforms in Turkey have been assessed by several international actors in terms of effectiveness and efficiency. For example, worldwide governance indicators of the World Bank evaluate the performance of countries in six dimensions: voice and accountability, political stability and absence of violence/terrorism, government effectiveness, regulatory quality, rule of law, and control of corruption. Each of these indicators are related to the public management reform processes discussed in the previous sections. When the figures for the selected years of 2009, 2014 and 2019 are examined, it can be seen that Turkey experienced a decline in all of the six indicators ${ }^{11}$, the most dramatic decrease being in voice and accountability indicator which fell from -0.06 to -0.81 .

The United Nations publishes EGDI indicators for 193 UN member states based on an assessment of national websites and how e-government policies and strategies are applied in general and in specific sectors for delivery of essential services. The e-government survey for the year $2020^{12}$ shows that Turkey moved from "high" EGDI group to "very high" EGDI group for the first time in 2020. In terms of online services indicators, Turkey is placed among very high EGDI countries as well. However, it is commented in the report that despite having highly developed human capital, Turkey's infrastructure might "be impeding further progress in e-government development" (p. 21). Turkey ranks 53 $3^{\text {rd }}$ among 193 countries evaluated by the UN in this regard, representing considerable improvement from its ranking at $80^{\text {th }}$ in $2012^{13}$.

The OECD is another institution which provides evaluation of member countries in terms of governance. The "OECD government at a glance" reports published every two years are based on "outcome indicators which cover core government results (e.g. trust, political efficacy, inequality reduction) and indicators on access, responsiveness, quality and satisfaction for the education, health and justice sectors" 14 . For example, in terms of trust in government and in political parties, Turkey scored considerably higher (around 50\%) than the OECD average in 2013, which was 30 percent. In terms of fundamental rights, Turkey scored 0.46 compared to the OECD average of 0.78 . The regulatory enforcement score

\footnotetext{
${ }^{11}$ https://info.worldbank.org/governance/wgi/Home/Reports.

${ }^{12}$ https://publicadministration.un.org/egovkb/Portals/egovkb/Documents/un/2020-Survey/2020\%20UN\%20

E-Government\%20Survey\%20(Full\%20Report).pdf.

${ }^{13} \mathrm{https} / /$ publicadministration.un.org/egovkb/Portals/egovkb/Documents/un/2012-Survey/CompleteSurvey.pdf

${ }^{14}$ https://www.oecd.org/gov/government-at-a-glance-22214399.htm
} 
of Turkey was 0.55 , whereas the OECD average was 0.72 . As for civil justice, Turkey performed lower $(0.58)$ than the OECD average (0.69). When we talk about the level of disclosure of private interests and public availability of information, which is an essential element of open government, Turkey's score was 50, which was almost equal to the OECD general score. In addition, citizens' confidence in local police, satisfaction with the education system and schools and satisfaction with the availability of quality health care was well below OECD average scores.

The 2021 report shows that between 2013 and 2021 confidence in the national government increased from $50 \%$ to $55 \%$ in Turkey whereas fundamental rights avalanched to 0.3 from 0.46 and the perception for effective enforcement of civil justice remained almost unchanged (60\%). Citizen satisfaction with the education system and schools, as well as citizen confidence in the judiciary system and the courts and the health care system, fell dramatically.

Finally, the United Nations Development Program's Turkey mission offers some valuable insights into the local governance reforms put into practice between 2003 and 2013. Emphasizing the strategic management dimension, the UNDP comments that success of strategic management in local governments has been limited, and "the planning, programming and budgeting functions of the strategic management framework do not work coherently". ${ }^{15}$

In summary, it can be concluded that public management reforms which were introduced in Turkey in the first two decades of the $21^{\text {st }}$ century have produced mixed results. It is not plausible to claim that the reform climate continues today in Turkey where public reforms are no longer a priority item on the political agenda (Öniş and Yılmaz, 2009; O’Connor et al., 2019; Bozkurt-Güngen, 2018). There are not any signs that the enthusiasm with reforms continues in central institutions and local governments. It is also difficult to see that the reforms made are fully implemented because legislative change often cannot radically change the functioning of public administration. The traditions and corporate culture that have emerged over the years may find ways among public officials to continue their old habits in the new public management era, but the requirements of the time and related concepts and processes will undoubtedly play a leading role in the continuity of the reform process in the public sector. These conclusions are in agreement with the findings of Sözen (2012), Gül (2016), Köseoğlu and Morçöl (2014), Akyüz and Hess (2018), Üstüner and Yavuz (2018), and Demir $(2018,2020)$.

This paper provides an evaluation of the evolution of public administration reforms in Turkey in the last two decades and argues that several factors come into play in urging decision-makers to introduce reforms in the public sphere. It can be seen that these reforms have not always been in line with international standards and tend to be influenced by the political-administrative landscape of the country. As a result, it can be claimed that several reform initiatives in Turkey have been tailored to meet the needs of political actors, first and foremost the central government.

\footnotetext{
${ }^{15}$ https://www.tr.undp.org/content/turkey/en/home/projects/tuerkiye_de-yerel-yoenetim-reformu-suerecininkurumsallamas-proj.html
} 


\section{REFERENCES}

Akbay, M. (2020) Türkiye’de merkezi yönetim ile yerel yönetimler arasinda görev bölüşümü [Division of roles between central government and local governments in Turkey]. Master’s thesis, Kırıkkale Üniversitesi Sosyal Bilimler Enstitüsü (in Turkish).

Akilli, H. and Akilli, H.S. (2014) 'Decentralization and recentralization of local governments in Turkey', Procedia-Social and Behavioral Sciences, 140, pp. 682-686.

Akyuz, K. and Hess, S. (2018) 'Turkey looks East: International leverage and democratic backsliding in a hybrid regime', Mediterranean quarterly, 29(2), pp. 1-26.

Alhomod, S.M., Shafi, M.M., Kousarrizi, M.N., Seiti, F., Teshnehlab, M., Susanto, H. and Batawi, Y.A. (2012) 'Best practices in E-government: A review of some innovative models proposed in different countries', International Journal of Electrical and Computer Sciences, 12(1), pp. 1-6.

Altan, Y. (2016) 'Türk Kamu Personel Rejiminde Reform İhtiyacı: Reformu Gerektiren Dış Etkenler Ekseninde Bir Değerlendirme' ['The need for reform in the Turkish Public personnel regime: An evaluation on the axis of external factors requiring reform'], Mehmet Akif Ersoy Üniversitesi Sosyal Bilimler Enstitüsü Dergisi, 8(15), pp. 381-398 (in Turkish).

Angın, C. and Övgün, B. (2020) 'Kamu Yönetiminde Yeni Bir Eğilim: Hibrit Merkezileşme' ['A new trend in public administration: Hybrid centralization'], Hacettepe Üniversitesi İktisadi ve İdari Bilimler Fakültesi Dergisi, 38(4), pp. 633-654 (in Turkish).

Ataay, F. (2008) 'Health reform and citizenship rights', Journal of Public Administration, 41, pp. 169-184.

Attar, M.A. (2020) 'Nüfus Politikalarinin Refah ve Büyüme Maliyetleri: Genel Denge Çözümlemesine Dayali Yeni Bulgular' ['Welfare and growth costs of population policies: New findings based on general equilibrium analysis'], Finans Politik and Ekonomik Yorumlar, 57(651), pp. 9-43 (in Turkish).

Aydin, O. (2019) 'Problems relating to the right to information in Turkey', in Constitutional Knowledge and Its Impact on Citizenship Exercise in a Networked Society. IGI Global, pp. 134-168.

Aydinoğlu, A.Ç. and Kara, A. (2019) 'Modelling and publishing geographic data with model-driven and linked data approaches: Case study of administrative units in Turkey' Journal of spatial science, 64(1), pp. 11-31.

Ayeni, V. (ed.) (2002) Public sector reform in developing countries: A handbook of commonwealth experiences. No. 14. Commonwealth Secretariat.

Bahçeci, H.İ. (2017) 'Urban transformation as the manifestation of neoliberalism. In urban space’, Uluslararası Yönetim Eğitim ve Ekonomik Perspektifler Dergisi, 5(1), pp. 36-47.

Basu, S. (2004) 'E-government and developing countries: An overview', International Review of Law, Computers and Technology, 18(1), pp. 109-132. 
Beswick, D. and Elstub, S. (2019) 'Between diversity, representation and 'best evidence': Rethinking select committee evidence-gathering practices', Parliamentary Affairs, 72(4), pp. 945-964.

Box, R.C., Marshall, G.S., Reed, B.J. and Reed, C.M. (2001) 'New public management and substantive democracy’, Public Administration Review, 61(5), pp. 608-619.

Bozkurt-Güngen, S. (2018) 'Labour and authoritarian neoliberalism: Changes and continuities under the AKP governments in Turkey', South European society and politics, 23(2), pp. 219-238.

Cass, D.Z. (1992) 'Word that saves Maastricht - the principle of subsidiarity and the division of powers within the European Community', The Common Market L. Rev., 29, p.1107.

Çetin, Z.Ö. (2015) 'The transformation of special provincial administration system in Turkey', Mediterranean Journal of Social Sciences, 6(3), p. 138.

Chen, Y.N., Chen, H.M., Huang, W. and Ching, R.K. (2006) 'E-government strategies in developed and developing countries: An implementation framework and case study', Journal of Global Information Management (JGIM), 14(1), pp. 23-46.

Çiner, C.U. (2014) 'Reconsidering the role of the prefects in Turkey: Public policies and metropolization', International Journal of Public Administration, 37(8), pp. 445-455.

Cox, G.W. and McCubbins, M.D. (2000) Political structure and economic policy: The institutional determinants of policy outcomes. PRESIDENTS, PARLIAMENTS, AND POLICY, Cambridge University Press. Available at: SSRN: https://ssrn.com/abstract=1009999 (accessed 17 September 2021).

Daniel, R.L. (1967) 'The United States and the Turkish Republic before World War II: The Cultural Dimension', Middle East Journal, 21(1), pp. 52-63.

Demir, F. (2018) 'Post-NPM and re-centralisation: Current themes in Europe and Turkey’, Journal of Contemporary European Studies, 26(2), pp. 149-164.

Demir, F. (2020) Public management reform in Turkey: The impact of Europeanization and beyond. Vol. 20. Springer Nature.

Dinçer, Ö. and Yılmaz, C. (2003) 'Kamu Yönetiminde Yeniden Yapılanma'. Değişimin Yönetimi İçin Yönetimde Değişim' ['Restructuring of public administration', in Change in management for the management of change]. Ankara: TC Başbakanlık Yayınları (in Turkish).

Doğan, K.C. (2020) 'Türk kamu yönetiminin denetlenmesinde yaşanan sorunlar ve çözüm önerileri' ['Problems in the supervision of Turkish public administration and suggested solutions'], OPUS-Uluslararası Toplum Araştırmaları Dergisi, 16(30), pp. 2994-3017. DOI: 10.26466/opus.705845 (in Turkish).

Duyck, S., Eschke, N. and Phung, S. (2018) National Human Rights Institutions and the 2018 UN Climate Conference: Incorporating human rights in the implementation guidelines of the Paris Agreement. Available at: https://nbn-resolving.org/urn:nbn:de:0168ssoar-59517-6 (downloaded 21 August 2021). 
Ege, R. and Hagemann, H. (2012) 'The modernisation of the Turkish University after 1933: The contributions of refugees from Nazism', The European Journal of the History of Economic Thought, 19(6), pp. 944-975.

Emini, F.T. and Ayaz Ç.E. (2018) 'Türkiye’de Bilgi Edinme Hakki: Büyükşehir Belediye Web Sayfalari Üzerinden Bir Değerlendirme' ['The right to information in Turkey: An evaluation through metropolitan municipality web pages'], Journal of Awareness, 3(1), pp. 13-26 (in Turkish).

Eryılmaz, B. (2008) 'Etik kültürü geliştirmek' ['Developing a culture of ethics'], Türk İdare Dergisi, 459, pp. 1-12 (in Turkish).

Fang, Z. (2002) 'E-government in digital era: concept, practice, and development', International journal of the Computer, the Internet and management, 10(2), pp. 1-22.

Follesdal, A. (1998) 'Subsidiarity', Journal of Political Philosophy, 6(2), pp. 231-259.

Follesdal, A. and Hix, S. (2006) 'Why there is a democratic deficit in the EU: A response to Majone and Moravcsik', JCMS: Journal of Common Market Studies, 44(3), pp. 533-562.

Frieden, J.A. (2004) 'One Europe, one vote? The political economy of European union representation in international organizations', European Union Politics, 5(2), pp. 261-276.

Goodhart, C. and Lastra, R. (2018) 'Populism and central bank independence', Open Economies Review, 29(1), pp. 49-68.

Grant, R.W. and Keohane, R.O. (2005) 'Accountability and abuses of power in world politics', American political science review, pp. 29-43.

Gül, H. (2016) 'Local, metropolitan and regional administration reforms in Turkey', in Yüksel Demirkaya (ed.) New Public Management in Turkey: Local Government Reform. New York: Routledge, p. 332.

Gül, H. and Kiriş, H.M. (2015) 'Democratic governance reforms in Turkey and their implications', in Dawoody A.R. (ed.) Public administration and policy in the Middle East. New York: Springer, pp. 25-59. DOI:10.1007/978-1-4939-1553-8

Güler, A. (2017) 'Oynak Ekonomik Koşullar Altında Döviz Kuru Oynaklığının Modellenmesi: Türkiye İçin Dinamik Zaman Serisi Analizi' ['Modeling exchange rate volatility under volatile economic conditions: Dynamic time series analysis for Turkey'], International Journal of Academic Value Studies, 3(14), pp. 39-47 (in Turkish).

Güneş, Ü. (2018) ‘Türkiyede İnsan Haklarinin Korunmasina İlişkin Ulusal İnsan Haklari Kurumlari: Kamu Denetçiliği Kurumu ve Türkiye İnsan Haklari ve Eşitlik Kurumu' ['National human rights institutions for the protection of human rights in Turkey: Ombudsman institution and human rights and equality institution of Turkey'], Trakya Üniversitesi Sosyal Bilimler Dergisi, 20(1), pp. 165-186 (in Turkish).

İbiş, H. and Akdağ, M. (2015) 'Bilgi Edinme Kanunundan Yararlanma Sıklı̆̆ı: Erciyes Üniversitesi Örneği (2011-2014)' ['Frequency of utilizing the law on access to information: The case of Erciyes university'], Erciyes Üniversitesi Sosyal Bilimler Enstitüsü Dergisi, 1(38), pp. 157-174 (in Turkish). 
Isik, S. and Singh, V.P. (2008) 'Hydrologic regionalization of watersheds in Turkey', Journal of Hydrologic Engineering, 13(9), pp. 824-834.

Kağitcioğlu, M. (2018) 'Kamu Denetçiliği Kurumunu (Türk Ombudsmanini) Yeniden Tasarlamak'['Redesigning the Turkish Ombudsman institution'], Anayasa Hukuku Dergisi, 7(14), pp. 457-512 (in Turkish).

Kapucu, N. and Palabıyı, H. (2008) Turkish public administration: From tradition to the modern age. Vol. 17). USAK books.

Kara, M.A. (2020) 'İhracata Dayalı Büyüme Hipotezinin Türkiye’de Bölgesel Düzeyde Test Edilmesi' ['Testing the export-led growth hypothesis at the regional level in Turkey'], Sosyoekonomi, 28(45), pp. 301-314 (in Turkish).

Karaca, P.Ö. and Atılgan, E. (2020) 'Sağlık Ekonomisinde Ekonomik Değerlendirme Teknikleri' ['Economic evaluation techniques in health economics'], Electronic Journal of Vocational Colleges, 10, pp. 28-40. Available at: https://dergipark.org.tr/en/pub/ejovoc (in Turkish).

Keers, R.N., Williams, S.D., Cooke, J. and Ashcroft, D. M. (2013) 'Causes of medication administration errors in hospitals: A systematic review of quantitative and qualitative evidence', Drug safety, 36(11), pp. 1045-1067.

Kettl, D.F. (2015) The transformation of governance: Public administration for the twentyfirst century. JHU Press.

Kirkpatrick, I., Ackroyd, S. and Walker, R. (2005) The new managerialism and public service professions. Hampshire: Palgrave Macmillan.

Koçak, S.Y. (2009) 'Turkish public administration in the European union process', Seria Stiiente Economice, 16, pp. 1-10.

Kukovič, S. and Justinek, G. (2020) 'Modernization Trends in Public Administration in Slovenia', Croatian and Comparative Public Administration, 20(4), pp. 623-647.

Köseoğlu, Ö. and Morçöl, G. (2014) 'Democratization of governance in Turkey: An assessment of the administrative reforms in the 2000s', in Challenges to Democratic Governance in Developing Countries. Springer, Cham, pp. 137-153.

Le Grand, J. (2009) The other invisible hand: Delivering public services through choice and competition. Princeton University Press.

Loewendahl-Ertugal, E. (2005) 'Europeanisation of regional policy and regional governance: The case of Turkey', European Political Economy Review, 3(1), pp. 18-53.

Mäeltsemees, S., Lõhmus, M. and Ratas, J. (2013) 'Inter-municipal cooperation: possibility for advancing local democracy and subsidiarity in Estonia', Halduskultuur, 14(1).

McNamara, K. (2002) 'Rational fictions: Central bank independence and the social logic of delegation', West European politics, 25(1), pp. 47-76.

Mulgan, R. (2007) 'Truth in government and the politicization of public service advice', Public Administration, 85(3), pp. 569-586. 
O’Connor, K., Janenova, S. and Knox, C. (2019) 'Open government in authoritarian regimes', International Review of Public Policy, 1(1), pp. 65-82.

Ohemeng, F.L. and Owusu, F.Y. (2014) 'Beyond neoliberal public sector reform', in Conteh Ch. and Huque A.Sh. (eds) Public Sector Reforms in Developing Countries: Paradoxes and Practices, New York: Routledge, p. 175.

Öktem, M.K. and Çiftçi, L. (2016) 'Vision of the public administration reform in Turkey', in Demirkaya, Y. (ed.) New Public Management in Turkey: Local Government Reform (1st ed.). Routledge, pp. 52-78. Available at: https://doi.org/10.4324/978131564128752-78 (downloaded 14 May 2021).

Olsen, J.P. (2017) Democratic accountability, political order, and change: Exploring accountability processes in an era of European transformation. Oxford University Press.

Onat, N. and Ersoz, S. (2011) 'Analysis of wind climate and wind energy potential of regions in Turkey', Energy, 36(1), pp. 148-156.

Ongaro, E. (2009). Public management reform and modernization: Trajectories of administrative change in Italy, France, Greece, Portugal and Spain. Edward Elgar Publishing.

Öniş, Z. and Yilmaz, Ş. (2009) 'Between Europeanization and Euro-Asianism: Foreign policy activism in Turkey during the AKP era', Turkish Studies, 10(1), pp. 7-24.

Özcan, B. (2018) 'Information and communications technology (ICT) and international trade: evidence from Turkey', Eurasian Economic Review, 8(1), pp. 93-113.

Özdemirci, F. (2008) 'Government records and records management: Law on the right to information in Turkey', Government Information Quarterly, 25(2), pp. 303-312.

Ozturk, D. (2015) 'Urban growth simulation of Atakum (Samsun, Turkey) using cellular automata-Markov chain and multi-layer perceptron-Markov chain models', Remote Sensing, 7(5), pp. 5918-5950.

Piotrowski, S. J. (2008) Governmental transparency in the path of administrative reform. The State University of New York: SUNY Press.

Radaelli, C.M. and Meuwese, A.C. (2009) 'Better regulation in Europe: between public management and regulatory reform’, Public Administration, 87(3), pp. 639-654.

Rhodes, R. A. W. (2000) 'Governance and Public Administration', in Pierre J. (ed.) Debating governance, authority, steering and democracy. Oxford, UK: Oxford University Press, pp. 54-90.

Rouban, L. (ed.) (1999) Citizens and the new governance: Beyond new public management. Vol. 3. IOS Press.

Savaş-Yavuzçehre, P. (2016) 'The effects of the law no. 6360 on metropolitan municipality system in Turkey', European Scientific Journal, 12(10).

Schick, A. (1996) The spirit of reform. Report prepared for the State Services Commission and the Treasury, New Zealand. 
Sezen, S. (2011) 'International versus domestic explanations of administrative reforms: The case of Turkey', International review of administrative sciences, 77(2), pp. 322-346.

Sharman, A. and Holmes, J. (2010) 'Evidence-based policy or policy-based evidence gathering? Biofuels, the EU and the 10\% target', Environmental Policy and Governance, 20(5), pp. 309-321.

Simon, H.A. (1972) 'Complexity and the representation of patterned sequences of symbols', Psychological review, 79(5), p. 369.

Soós, E. (ed.) (2016) Challenges of Public Administration in Turkey. Scientific cooperation. Scientific cooperation's 2nd International conference on social sciences, 2-3 April 2016, Istanbul-Turkey.

Sozbilir, M. and Kutu, H. (2008) 'Development and current status of science education research in Turkey', Essays in Education, 24(1), pp. 3.

Sözen, S. (2012) 'Recent administrative reforms in Turkey: A preliminary assessment', International Journal of Business and Social Science, 3(9).

Sözen, S. and Shaw, I. (2002) 'The international applicability of "new" public management: Lessons from Turkey’, International Journal of Public Sector Management.

Topal, M.H. (2018) 'Türkiye'de askeri harcamalar ile ekonomik büyüme arasındaki ilişkinin bir analizi (1960-2016)' ['An analysis of the relationship between military expenditures and economic growth in Turkey (1960-2016)'], Maliye Dergisi, 174, pp. 175-202 (in Turkish).

Torlak, S.E. and Sezer, Y. (2005) Büyükşehir Belediye Reformu Üzerine Bir Değerlendirme. Yerel Yönetim Üzerine Güncel Yazılar-I: Reform [An evaluation on metropolitan municipality reform in Current articles on local government-I: Reform], Nobel Yayınevi, Ankara (in Turkish).

Üstüner, Y. and Yavuz, N. (2018) 'Turkey's public administration today: An overview and appraisal', International Journal of Public Administration, 41(10), pp. 820-831.

Van den Bergh, R. (1994) 'The subsidiarity principle in European Community law: Some insights from law and economics', Maastricht Journal of European and Comparative Law, 1(4), pp. 337-366.

Vischer, R.K. (2001) 'Subsidiarity as a principle of governance: Beyond devolution', Indiana Law Review, 35, p.103.

Yayman, H. (2008) Türkiye’nin idari reform tarihi. [Turkey's administrative reform history]. Turhan Kitabevi Yayınları (in Turkish).

Zanotti, J. (2016) Turkey: Background and US relations in brief. Washington United States, Congressional Research Service.

The article was submitted 25.02.2021; approved after reviewing 14.09.2021; accepted for publication 28.11.2020. 